\title{
PENGARUH BRAND IMAGE, BRAND TRUST, DAN PRICE PERCEPTION TERHADAP PURCHASE INTENTION PELANGGAN UNIQLO DI JAKARTA
}

\author{
Kelvin', Carunia Mulya Firdausy² \\ ${ }^{1}$ Program Studi Manajemen, Fakultas Ekonomi dan Bisnis, Universitas Tarumanagara \\ Email: kelvin.115170024@stu.untar.ac.id \\ ${ }^{2}$ Program Studi Manajemen, Fakultas Ekonomi dan Bisnis, Universitas Tarumanagara* \\ Email: caruniaf@pps.untar.ac.id \\ *Penulis Korespondensi
}

\begin{abstract}
ABSTRAK
Penelitian ini bertujuan untuk mengetahui pengaruh Brand Image, Brand Trust, dan Price Perception terhadap Purchase Intention pelanggan Uniqlo di Jakarta. Populasi penelitian ini adalah 250 responden yang merupakan pelanggan Uniqlo di Jakarta. Metode convenience sampling digunakan dengan menyebarkan kuesioner secara online yang kemudian diolah menggunakan program SPSS versi 25. Hasil penelitian menunjukkan bahwa Brand Image, Brand Trust dan Price Perception berpengaruh signifikan dan positif terhadap Purchase Intention pelanggan Uniqlo di Jakarta. Oleh karena itu, Uniqlo harus tetap mempertahankan ketiga variabel tersebut untuk meningkatkan Purchase Intention pengguna produk PT Uniqlo.
\end{abstract}

Kata Kunci: Citra Merek, Kepercayaan Merek, Persepsi Harga, Niat Beli, Uniqlo.

\section{ABSTRACT}

This study aims to determine the effect of Brand Image, Brand Trust, and Price Perception on the Purchase Intention of Uniqlo customers in Jakarta. The sample respondents was 250 respondents who are Uniqlo customers in Jakarta. The convenience sampling method was used by distributing online questionnaires which were then analysed by using multiple regression method. The results showed that Brand Image, Brand Trust, and Price Perception had a significant and positive effect on Purchase Intention of Uniqlo customers in Jakarta. Therefore, Uniqlo must improve those above three variables to increase the Purchase Intention of product users.

Keywords: Brand Image, Brand Trust, Price Perception, Purchase Intention, Uniqlo

\section{PENDAHULUAN}

\section{Latar Belakang}

Usaha ritel pakaian merupakan suatu bisnis yang berkembang tinggi. Bisnis retail ini sudah berjalan sejak tahun 1980an di Indonesia sesuai dengan kemajuan perekonomian Indonesia (Martinus, 2011). Dari banyaknya bisnis retail pakaian tersebut, Uniqlo merupakan salah satu perusahaan yang bergerak dalam bisnis tersenut. Perusahaan ini melakukan penawaran pakaian dalam bentuk fashion maupun lifestyle. Awalnya perusahaan Uniqlo ini melakukan bisnis di kota Hiroshima, Jepang sejak tahun 1984. Pada saat itu nama perusahaan ini yaitu Unique Clothing Warehouse. Sebutan Uniqlo tersebut muncul akibat dari pergabungan dari nama perusahaan tersebut.

Namun pada tahun 1990-an sistem perekonomian dari Jepang mengalami penurunan. Hal ini membuat beberapa pakaian dari produk Uniqlo menjadi sangat terjangkau. Perusahaan Uniqlo menjadi terkenal karena dipengaruhi dari banyaknya pembeli di Jepang. Uniqlo sendiri memiliki 
lokasi di berbagai Negara khususnya di Jepang dan juga ada di Negara Singapura, Malaysia, Amerika Serikat, China, Filipina, Taiwan, Perancis dan Indonesia.

Pada Gambar 1 ditunjukkan bahwa Uniqlo merupakan merek Apparel dengan berada di peringkat ke 7 yang naik sebesar $40 \%$ pada tahun 2019. Ini menunjukkan bahwa merek Uniqlo mengalami dibandingkan dengan merek pakaian lainnya.

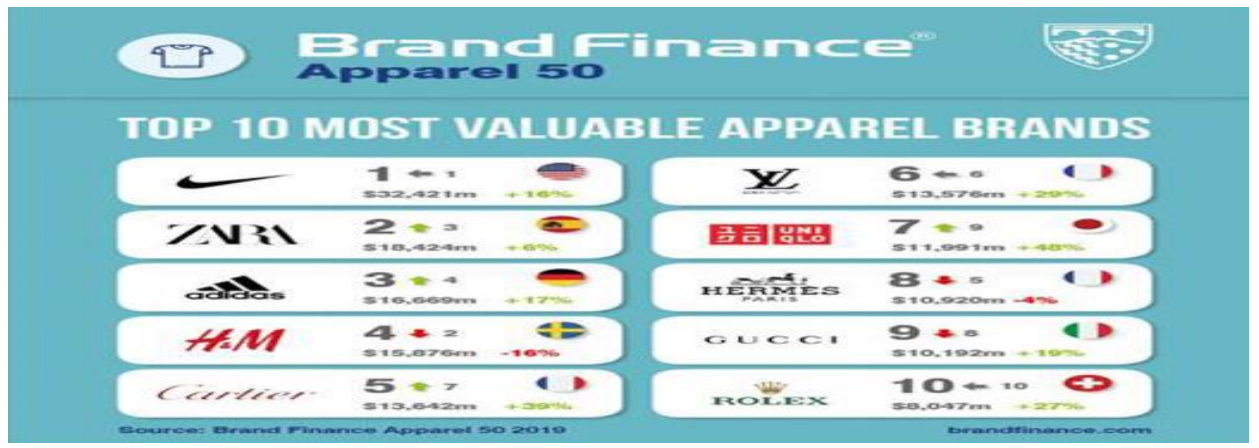

Gambar 1. Valuable apparel brands

(Sumber: brandfinance.com)

Pada Tabel 1 di bawah ini ditunjukkan bahwa bisnis retail Indonesia berada posisi 5 diantara 200 negara berkembang dengan nilai penjualan sebesar 396 miliar dollar AS pada tahun 2019. Berdasarkan besarnya nilai penjualan tersebut, maka dapat dikatakan Purchase Intention konsumen Indonesia terhadap bisnis retail sangat tinggi.

Tabel 1. Kenaikan niat membeli terhadap bisnis ritel

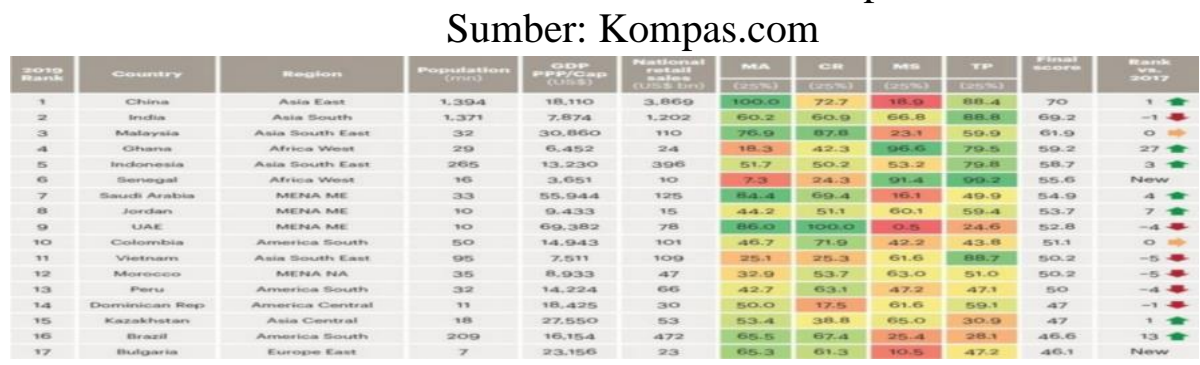

Dari penelitian terdahulu diungkapkan bahwa Purchase Intention dipengaruhi oleh Brand Image, Brand Trust dan Price Perception. Usep Suhud dan Greg Wilson (2019), penelitian ini mendapatkan bahwa Brand Image mempunyai pengaruh signifikan dengan Purchase Intention, Brand Trust dan Price Perception. selain Brand Image, Becerra dan Badrinarayanan (2013), menemukan bahwa Brand Trust mempengaruhi Purchase Intention secara signifikan dan positif yang diakibatkan oleh tingginya kepercayaan konsumen terhadap merek tersebut. Sedangkan penelitian Mirza dan Ali (2017), menyatakan bahwa Price Perception mempengaruhi Purchase Intention secara positif dan signifikan, suatu persepsi harga akan berpengaruh terhadap niat membeli konsumen yang ingin mendapatkan harga yang termurah dan kualitas barang yang terbaik sehingga munculnya niat membeli. Hasil penelitian di atas berbeda dengan hasil penelitian Jihyun Lee and Yuri Lee (2018), penelitian ini menghasilkan bahwa Brand Image tidak memiliki pengaruh secara langsung terhadap minat seseorang dalam membeli produk, tetapi secara positif mempengaruhi dengan dimediasi oleh variabel Image perusahaan. Dari penelitian ini didapatkan bahwa Brand Image harus di mediasi dengan variabel Image perusahaan. 
Hasil penelitian diatas menarik diteliti kembali untuk memperjelas apakah Brand Image, Brand Trust, Price Perception berpengaruh terhadap Purchase Intention. Oleh karena itu, penelitian ini ditunjukkan untuk meneliti "Pengaruh Brand Image, Brand Trust dan Price Perception terhadap Purchase Intention Pelanggan Uniqlo di Jakarta"

\section{Landasan Teori, Kerangka Pemikiran dan Hipotesis}

Landasan teori yang digunakan yakni Theory Prospect. Teori ini merupakan suatu teori yang digunakan seseorang ketika mengambil suatu keputusan dalam ketidakpastian (Kahneman \& Tversky, 1979). Theory Prospect yang dikemukakan oleh Kahneman \& Tversky (1979). menjelaskan bahwa seseorang akan melakukan survey dan mengumpulkan informasi yang akan dibentuk dalam konsep keputusan. Ketika suatu konsep keputusan ini sudah jadi maka seseorang dapat memutuskan untuk memilih konsep yang mana yang digunakan. Teori ini menjelaskan bahwa sifat orang memiliki sifat yang irasional. Artinya orang tidak selalu mementingan keuntungan atau kerugian.

Selain teori di atas, teori lain yang digunakan yakni Theory of Planned Behavior. Teori ini merupakan teori yang dapat mengukur suatu perilaku individu yang lebih terperinci (Ajzen, 1991). Teori ini mengambarkan bahwa individu dapat menentukan apa yang dikonsepkan. Niat perilaku yang dapat dipengaruhi dari suatu kepercayaan atas keberhasilan pada waktu tertentu.

Teori ini dapat digunakan dalam menganalisis niat membeli individu terhadap suatu produk tersebut. Suatu sikap yang dimiliki oleh konsumen akan memiliki peranan penting dalam melakukan pemilihan produk. Kepercayaan merek juga memiliki fungsi yang penting karena kosumen akan membeli produk yang mereka percaya. Variabel Purchase Intention berdasarkan hasil literature di pengaruhi oleh banyak faktor, di antara banyak faktor itu ada 3 faktor, yaitu Brand Image, Brand Trust dan Price Perception. Pengaruh Brand Image, misalnya dapat meningkatkan Purchase Intention karena citra merek memiliki nilai positif terhadap merek yang menjadi acuan untuk meningkatkan keyakinan dalam membeli barang tersebut. Pengaruh Brand Trust dapat meningkatkan Purchase Intention karena kepecayaan merek dapat meningkatkan nilai positif terhadap pembelian atas produk, sehingga perusahaan harus meningkatkan keyakinan terhadap suatu produk tersebut.

Pengaruh Price Perception dapat meningkatkan Purchase Intention karena konsumen dalam melakukan pembelian atas produk tersebut konsumen akan melihat harga yang ditawarkan dan kualitas barang yang terbaik sehingga munculnya niat membeli atas merek tersebut. Maka kerangka pemikiran sebagai berikut (Gambar 2):

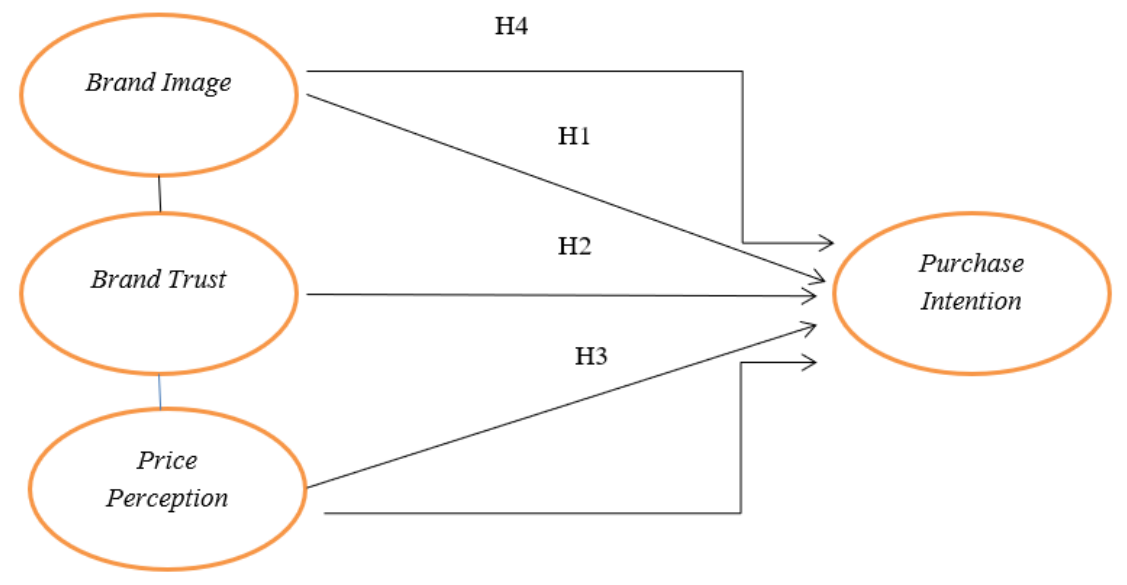

Gambar 2. Kerangka pemikiran 
Berdasarkan kerangka pemikiran diatas, disusun hipotesis sebagai berikut:

H1: Brand Image berpengaruh terhadap Purchase Intention.

$\mathrm{H} 2$ : Brand Trust berpengaruh terhadap Purchase Intention.

H3: Price Perception berpengaruh terhadap Purchase Intention.

H4: Brand Image, Brand Trust dan Price Perception berpengaruh terhadap Purchase Intention.

\section{METODE PENELITIAN}

Desain penelitian ini yakni desain penelitian deskriptif. Dalam desain ini dilakukan analisis deskriptif atas temuan analisis data yang diolah secara statstik dengan menyebarkan daftar pertanyaan kepada pelanggan Uniqlo di Jakarta.

Populasi penelitian ini yakni semua pelanggan Uniqlo di Jakarta. Namun karena jumlah populasi tidak diperoleh maka digunakaan sampleTeknik pemilihan sampel yang digunakan yaitu nonprobability sampling. Sedangkan cara pengumpulan data dilakukan dengan convenience sampling. Cara ini dipilih karena biaya yang dibutuhkan lebih terjangkau dan mempersingkat waktu. Jumlah sampel yang diambil dalam penelitian ini yaitu 250 responden yang merupakan konsumen Uniqlo di Jakarta. Adapun kriteria responden yang disampel yaitu pernah menggunakan produk Uniqlo. Dalam penelitian ini peneliti membuat data kuesioner melalui media google form yang penyebaran kuesioner ini dibantu dengan menggunakan media social seperti Whatsapp, Instragram dan Line. Dalam penelitian ini kuantifikasi terhadap data setiap variabel menggunakan skala likert dengan score skala likert 1-5 yang berisi sangat tidak setuju, tidak setuju, netral, setuju dan sangat setuju.

\section{HASIL DAN PEMBAHASAN}

\section{Hasil Analisis Validitas}

Hasil analisis validitas pada variabel Brand Image, Brand Trust, Price Perception dan Purchase Intention memenuhi syarat Corrected Item-Total Correlation karena nilai $\mathrm{R}$ hitung di atas $\mathrm{R}$ tabel sehingga semua indikator pada variabel tersebut dinyatakan valid.

\section{Hasil Analisis Reliabilitas}

Hasil uji reliabilitas menunjukkan bahwa semua variabel pada Brand Image, Brand Trust, Price perception dan Purchase Intention dinyatakan reliable karena nilai Cronbach's Alpha > 0,6.

\section{Hasil Uji Normalitas}

Pengujian normalitas dilakukan untuk mengetahui apakah suatu distribusi yang dilakukan terhadap variabel independen dan variabel dependen bersifat normal atau tidak normal. Dengan menggunakan transformasi data dengan rumus SQRT(k-x), dihasilkan nilai signifikansi sebesar 0,061. Angka ini diatas 0,05 yang berarti data tersebut bersifat normal.

\section{Hasil Uji Multikolinearitas}

Uji Multikolonieritas dilakukan untuk menguji apakah suatu model regresi terdapat hubungan korelasi antar variabel independen. Dengan menghitung besaran Variance Inflation Factor (VIF) diperoleh hasil nilai Variance Inflation Factor pada variabel Brand Image, Brand Trust dan Price Perception tidak memliki multikolinearitas.

\section{Hasil Uji Heterokedastisitas}

Uji heteroskedastisitas dilakukan untuk mengetahui apakah terdapat perbedaan variansi residual dalam suatu model regresi. Heteroskedastisitas terjadi apabila data residual memiliki variansi berbeda-beda. Pengujian ini dilakukan dengan cara melihat scatter plot dan Sig $<0,05$. Hasil 
pada nilai Signifikan pada setiap variabel memiliki nilai di bawah 0,05 dengan ini dikatakan tidak terdapat heteroskedastisitas.

\section{Hasil Analisis Regresi Berganda}

Hasil Analisis Regresi Berganda yang didapat adalah:

$\mathrm{PI}=5,224+0,119 \mathrm{BI}+0,240 \mathrm{BT}+0,365 \mathrm{PP}$

Penjelasan:

a) Nilai konstanta $\mathrm{a}=5,224$, artinya jika variabel Brand Image, Brand Trust, Price Perception bernilai nol, maka Purchase Intention konsumen yakni sebanyak 5,2 satuan.

b) Nilai koefisien BI $=0.119$, artinya jika variabel Brand Image berubah sebesar 1 unit satuan, maka Purchase Intention akan berubah sebesar 0.119 unit satuan dengan asumsi variabel independen yang lain konstan.

c) Nilai koefisien BT $=0.240$ artinya jika variabel Brand Trust berubah sebesar 1 unit satuan, maka Purchase Intention akan berubah sebesar 0.240 unit satuan dengan asumsi variabel independen yang lain konstan.

d) Nilai koefisien PP $=0.365$ artinya jika variabel Price Perception berubah sebesar 1 unit satuan, maka Purchase Intention akan berubah sebesar 0.365 unit satuan dengan asumsi variabel independen yang lain konstan.

\section{Hasil Uji Anova (F)}

Hasil pengujian Anova ditunjukkan pada tabel 2. Pada tabel ini dapat diperhatikan nilai $F$ hitung yang diperoleh yakni 49,577. Angka ini lebih besar dari nilai F table. Demikian pula nilai $\mathrm{F}$ sig diperoleh sebesar 0.379 dibawah nilai Sig 0,05 . Nilai $F$ ini mengindikasikan Ho ditolak dan berarti Brand Image, Brand Trust, Price Perception bersama - sama berpengaruh signifikan terhadap Purchase Intention pakaian Uniqlo (Tabel 2).

Tabel 2. Hasil Uji Anova (F)

Sumber: data diolah dari kuesioner

\begin{tabular}{|l|c|c|c|c|c|}
\hline \multicolumn{1}{|c|}{ Model } & Sum of Squares & Df & Mean Square & $F$ & Sig. \\
\hline Regression & 257,694 & 3 & 85,898 & 49,577 & $0,000^{\mathrm{b}}$ \\
\hline Residual & 427,955 & 247 & 1,733 & & \\
\hline Total & 685,649 & 250 & & & \\
\hline
\end{tabular}

\section{Hasil Uji Koefisien Determinasi $\left(\mathbf{R}^{2}\right)$}

Hasil pengujian koefisien determinasi diperoleh nilai 0,368 . Nilai ini menunjukkan variabel Brand Image, Brand Trust dan Price Perception hanya mampu menjelaskan pengaruhnya pada Purchase Intention konsumen Uniqlo sebesar 36,8\% saja. Sedangkan sisanya sebesar 63,2\% dijelaskan oleh variabel lain diluar model regresi ini (Tabel 3).

Tabel 3. Hasil Uji Koefisien Determinasi Brand Image, Brand Trust, Price Perception terhadap Purchase Intention

Sumber: data diolah dari kuesioner

\begin{tabular}{|c|c|}
\hline Model & Adjusted $R$-Square \\
\hline 1 & 0,368 \\
\hline
\end{tabular}

\section{Hasil Uji-t}

Uji-t dilakukan untuk melihat variabel independen manakah yang berpengaruh terhadap variabel dependen. Apabila nilai signifikansi < 0,05 maka dikatakan bahwa Ho diterima dan 
terdapat pengaruh signifikan terhadap variabel tersebut dan sebaliknya. Pada Tabel 3 diberikan nilai t dan nilai Sig masing-masing variable bebas (Tabel 4).

Tabel 4. Hasil Uji t

Sumber: data diolah dari kuesioner

\begin{tabular}{|c|c|c|c|}
\hline & $\begin{array}{c}\text { Unstandardized } \\
\text { Coefficients }\end{array}$ & $\mathrm{t}$ & \multirow{2}{*}{ Sig. } \\
\cline { 2 - 3 } & $\mathrm{B}$ & 3,570 & 0,000 \\
\hline (Constant) & 5,224 & 2,531 & 0,012 \\
\hline Brand Image & 0,119 & 3,403 & 0,001 \\
\hline Brand Trust & 0,240 & 5,371 & 0,000 \\
\hline Price Perception & 0,365 & & \\
\hline
\end{tabular}

Dari Tabel 4 dapat dinyatakan sebagai berikut.

H1: Brand Image berpengaruh positif signifikan terhadap Purchase Intention pelanggan Uniqlo di Jakarta. Hal ini karena nilai Sig pada Brand Image yaitu sebesar 0,012 memiliki nilai lebih kecil dari a =0,05. Oleh karena itu Brand Image berpengaruh signifikan terhadap Purchase Intention pada pelanggan Uniqlo.

H2: Brand Trust berpengaruh positif signifikan terhadap Purchase Intention pelanggan Uniqlo di Jakarta. Hal ini karena nilai Sig pada Brand Trust yaitu sebesar 0,001 yang berada di bawah nilai a $=0,05$. Ini berarti Brand Trust berpengaruh signifikan terhadap Purchase Intention pada pelanggan Uniqlo.

H3: Price Perception berpengaruh positif signifikan terhadap Purchase Intention pelanggan Uniqlo di Jakarta. Nilai Sig pada Price Perception yaitu sebesar 0,001 yang berada di bawah nilai $\mathrm{a}=0,05$. Dengan demikian dapat disimpulkan bahwa Price Perception berpengaruh signifikan terhadap Purchase Intention pada pelanggan Uniqlo.

Untuk hipotesis H4, hasilnya menunjukkan bahwa Brand Image, Brand Trust, Price Perception berpengaruh positif terhadap Purchase Intention. Kesimpulan ini ditunjukkan dari hasil nilai $\mathrm{F}$ hitung yang lebih besar dari $\mathrm{F}$ tabel dan nilai $\mathrm{F}$ sig yang lebih kecil dari 0,05 .

\section{Pembahasan}

Seperti dijelaskan terdahulu dibagian hasil bahwa Brand Image berpengaruh positif dan signifikan terhadap Purchase Intention pelanggan Uniqlo. Hasil ini mendukung penelitian Usep Suhud dan Greg Wilson (2019), bahwa Brand Image mempunyai pengaruh signifikan dan positif terhadap Purchase Intention. Hal ini karena Uniqlo merupakan sebuah perusahaan ritel pakaian yang terkenal. Apabila Uniqlo meningkatkan citra merek terhadap produk mereka maka Purchase Intention terhadap Uniqlo mengalami peningkatan. Dengan kata lain, Semakin baik kualitas yang diberikan oleh Uniqlo maka citra positif Uniqlo menjadi baik sehingga membuat pelanggan Uniqlo tertarik untuk melakukan pembelian terhadap produk tersebut.

Selanjutnya juga ditemukan bahwa Brand Trust berpengaruh positif dan signifikan terhadap Purchase Intention pelanggan Uniqlo. Hasil ini mendukung hasil penelitian Becerra dan Badrinarayanan (2013), bahwa Brand Trust dapat mempengaruhi Purchase Intention secara signifikan dan positif. Ini berarti semakin tinggi kepercayaan merek yang diberikan oleh suatu produk, maka semakin tinggi komitmen konsumen terhadap suatu produk tersebut. Kepercayaan merek memiliki respon yang positif terhadap niat membeli konsumen sehingga 
kepercayaan merek Uniqlo sangat dibutuhkan oleh konsumen agar dapat percaya terhadap merek tersebut.

Kemudian juga ditemukan bahwa Price Perception juga berpengaruh positif dan signifikan terhadap Purchase Intention pelanggan Uniqlo. Hasil penelitian ini mendukung penelitian Mirza dan Ali (2017), yang menyatakan bahwa Price Perception dapat mempengaruhi Purchase Intention secara positif dan signifikan. Hal ini karena seorang pelanggan akan melakukan survey terhadap harga yang ditawarkan karena ketika melakukan suatu pembeli terhadap suatu produk konsumen akan membandingkan harga dari satu produk dengan produk lainnya. Ketika harga yang ditawarkan semakin tinggi membuat konsumen melakukan evaluasi dalam melakukan keputusan pembelian terhadap produk tersebut. Berbanding terbalik apabila harga yang ditawarkan relative terjangkau membuat konsumen tidak melakukan evaluasi dalam melakukan keputusan pembelian terhadap produk tersebut. Dengan ini Uniqlo harus menawarkan harga yang relative terjangkau dan kualitas yang baik agar dapat menarik konsumen dalam melakukan pembelian terhadap produk Uniqlo.

Hipotesis 4 disimpulkan bahwa Brand Image, Brand Trust dan Price Perception berpengaruh positif dan signifikan terhadap Purchase Intention. Hal tersebut sejalan dengan hasil penelitian dari Usep Suhud dan Greg Wilson (2019), bahwa Brand Image berpengaruh signifikan dengan Purchase Intention. Hasil penelitian Becerra dan Badrinarayanan (2013), bahwa Brand Trust mempengaruhi Purchase Intention secara positif dan signifikan dan hasil penelitian Mirza dan Ali (2017), menyatakan bahwa Price Perception mempengaruhi Purchase Intention secara positif dan signifikan. Dengan hasil tersebut maka Brand Image Uniqlo harus tetap konsisten karena berperan penting dalam meningkatkan niat membeli konsumen, selanjutnya Brand Trust juga berperan penting dalam meningkatan pembelian produk Uniqlo sehingga Uniqlo harus mempertahankan kepecayaan yang sudah diberikan kepada konsumen dan Price Perception juga dibutuhkan dalam menjaga konsisten terhadap harga yang diberikan oleh produk Uniqlo sehingga konsumen tertarik untuk melakukan pembelian produk tersebut.

\section{KESIMPULAN DAN SARAN}

Berdasarkan hasil perhitungan dan analisis, maka dapat disimpulkan sebagai berikut :

1. Brand Image berpengaruh signifikan dan positif terhadap Purchase Intention pelanggan Uniqlo di Jakarta.

2. Brand Trust berpengaruh signifikan dan positif terhadap Purchase Intention pelanggan Uniqlo di Jakarta.

3. Price Perception berpengaruh signifikan dan positif terhadap Purchase Intention pelanggan Uniqlo di Jakarta.

4. Secara bersama-sama Brand Image, Brand Trust, dan Price Perception berpengaruh terhadap variabel dependen Purchase Intention pelanggan Uniqlo di Jakarta.

\section{REFERENSI}

Ajzen, I. (1991). The Theory of Planned Behavior. Organizational Behavior and Human Decision Processes, 50(2), 179-211.

Becerra, P. E. \& Badrinarayanan, V. (2013). The influence of brand trust and brand identification on brand evangelism. Journal of Product and Brand Management, 22(5/6), 371-383.

Hanjani, G. A. \& Widodo, A. (2019). Consumer Purchase Intention: The Effect of Green Brand and Green Knowledge on Indonesian Nestle Company. Jurnal Sekretaris \& Administrasi Bisnis, 3(1), 39-50. 
Lee, J. \& Lee, Y. (2018). Effects of multi-brand company's CSR activities on purchase intention through a mediating role of corporate image and brand image. Journal of Fashion Marketing and Management, 22(2), 387-403.

Mirza, B. \& Ali, M. (2017). An Assessment among Service Quality, Price Perception and Customer Satisfaction in the Formation of Consumer's Purchase Intention. Arabian Journal of Business and Management Review (Kuwait Chapter), 6(12), 10-21.

Praptono, L. H. \& Haryanto. (2016). Purchase Intention: Do E-Servicescape Has Effect? Jurnal Manajemen dan Kewirausahaan, 14(2), 101-114.

Supriyadi, Y. F. \& Indra, G. (2016). Pengaruh kualitas produk dan brand image tehadap keputusan pembelian. Jurnal Bisnis dan Manajemen, 3(1), 135-144.

Yu, M., Liu, F., Lee, J. \& Soutar, G. (2018). The influence of negative publicity on brand equity: attribution, image, attitude and purchase intention. Journal of Product \& Brand Management, 27(4), 440-451. 